\title{
The Evaluation of Secondary School's Fifth Grade Social Studies Curriculum
}

\author{
Gürbüz Ocak ${ }^{1}$, Zeynep Gökteke ${ }^{2 *}$
}

${ }^{1}$ Afyon Kocatepe University, TURKEY

${ }^{2}$ Social Studies Teacher in Afyon Kocatepe Secondary School, TURKEY

*Corresponding Author: zeynepgokteke@windowslive.com

Citation: Ocak, G., \& Gökteke, Z. (2020). The Evaluation of Secondary School's Fifth Grade Social Studies Curriculum. Mediterranean Journal of Social \& Behavioral Research, 4(1), 3-9. https://doi.org/10.30935/mjosbr/9595

\begin{abstract}
The studies state that there have been come across some problems, shortcomings and insufficiencies during the implementation of renewed Social Studies Curriculum based on constructivist approach in Turkey. The purpose of this paper is to evaluate the Fifth Grade Social Sudies Curriculum in terms of its needs assessment, goals, content, teaching-learning process and assessment process subject to curriculum development basis. The data was collected through "Curriculum Evaluation Analysis Form", developed by an academic in Curriculums and Instruction Department of Afyon Kocatepe University and 3 doctoral students in the same area and analyzed through document analysis. The reliabilty of scale was calculated as 0.8 . It is concluded that the curriculum was developed on the basis of constructivist approach in terms of its objectives, content, teaching-learning process and assessment process, but it is seen that the objectives are determined without consideration of students' intrest and level and also there is disregardation of regional discrepancies in the process of determination of needs.

Keywords: social studies curriculum, evaluation, social studies course, components of curriculum

Received: 12 Oct. $2019 \bullet$ Revised: 13 Feb. $2020 \bullet$ Accepted: 04 Mar. 2020
\end{abstract}

\section{INTRODUCTION}

Social Studies is quite important in terms of preparing children for life, and providing them with specific habits and skills in Primary school. National Council for the Social Studies (1994) defines social studies as:

\footnotetext{
...the integrated study of the social sciences and humanities to promote civic competence. Within the school curriculum, social studies provides coordinated, systematic study drawing upon such disciplines as anthropology, archaeology, economics, geography, history, law, philosophy, political science, psychology, religion, and sociology, as well as appropriate content from the humanities, mathematics, and natural sciences. The primary purpose of social studies is to help young people make informed and reasoned decisions for the public good as citizens of a culturally diverse, democratic society in an interdependent world.
}

According to the Council (1994), the aim of social studies is "the promotion of civic competence-the knowledge, intellectual processes, and democratic dispositions required of students to be active and engaged participants in public life." In parralel with this contemporary definition, Ministery of National Education (2005a) redefined Social Studies as "to be engaged to assist the individual social existence; history, geography, economics, sociology, anthropology, psychology, philosophy, political science and law topics that reflect the social studies and civics; learning areas comprising combining under one unit or theme; human interaction with the social and physical environment of the past, present and future is examined in the context; it is established as a primary school course starting from the concept of public education" and in this context, major structural changes were with the concept of learning, curriculum, textbooks, and classroom activities in the social studies curriculum in Turkey in 2004.

In general, the renewed Social Studies Curriculum brings an innovative perspective. Student- centered and individual differences are further emphasized in this curriculum, thematic approach is taken into account in the regulation of content and learning areas have been identified in this framework. One of the most significant changes reflected in the new curriculum is the identification of inter disciplinary objectives and associated them with learning areas. Teachers are given roles as guide, as well as co-providers, utility, facilitating self-developer, planner, router, a person accounts of individual differences (ERG Report, 2005).

In addition to this, it is observed that the new curriculum focuses on skills. The skills such as critical thinking, creative thinking, communication, problem solving, research, decision making and using information technologies, being entrepreneurial, concerning on personal and social values are highlighted in the curriculum. Activites 
which will enable students to participate in research, inquiry, problemsolving and decision-making processes are proposed to use. Additionally, it is emphasized the importance of "making-thinking" learning activities and cooperative learning strategies are intended to be used as required. In the development process, activities are developed through the theory of Multiple Intelligences from time to time. In the curriculum, not only learning outcomes but also process evaluation oriented alternative assessment methods have been used (ERG Report, 2005). When considered from this point of view, the social studies curriculum has been shown to bring innovative arrangements by taking into account modern developments.

Several evaluation studies have been conducted for different aspects of the renewed curriculum since the implementation of it and some problems, shortcomings and deficiencies have been identified. A study to assess the social studies curriculum, Doğanay (2008) has found that there are some problems systematically in terms of the dynamic relationship between the elements of the curriculum. Arslan and Şahiner (2010), Ataman ve Kabapinar (2012), Ersoy ve Kaya (2009), Semenderoğlu ve Gülersoy (2005), Kesten ve Özdemir (2010), Akengin ve Demirsoy (2011), Adanalı (2008), Gömleksiz ve Öner (2013), Keçe ve Merey (2011), Yaşar (2005), Kayhan ve Tokcan (2013), Turan, Dönmez ve Çakmak (2009), İnce (2005), Aslan ve Tetik (2013), Aykaç (2007), Kaymakçı (2012), Kalaycıoğlu (2007), Memişoğlu (2012), Karacaoğlu (2010), Gelbal ve Kelecioğlu (2007) encountered with various problems in the implementation of the curriculum in their works which seem to support the findings. Considering overall evaluation studies of the curriculum, it is found that most of the them have evaluated the curriculum based on teachers' and students' opinions. In this context, the number of studies about the evaluation of 5th Grade Social Studies curriculum through analysis form based on expert views is relatively small. Therefore, the aim of this study is to evaluate the renewed Fifth Grade Social Studies Curriculum mainly in terms of compliance with the requirements of the curriculum development foundations. For this purpose, it will be sought to answer the following sub-problems:

1. What is the compliance level of the fifth grade social studies curriculum studies in terms of the needs assessment?

2. What is the compliance level of the fifth grade social studies curriculum studies in terms of the objectives component of the curriculum?

3. What is the compliance level of the fifth grade social studies curriculum studies in terms of the content component of the curriculum?

4. What is the compliance level of the fifth grade social studies curriculum studies in terms of the teaching-learning process of the curriculum?

5. What is the compliance level of the fifth grade social studies curriculum studies in terms of the assessment process of the curriculum?

\footnotetext{
${ }^{1}$ The Analysis Form was developed through Assoc. Prof. Gürbüz Ocak's* views who is an academic in Department of Education, in Curriculum and Instruction, in Faculty of Educational Sciences in Afyonkarahisar Kocatepe University, and three teachers' views**, Ramazan Yurtseven, Zeynep Gökteke ve Emine Akkas Baysal, who are making doctoral studies in the same field. ${ }^{* * *}$ The Analysis Form
}

Table 1. Range table

\begin{tabular}{lcc}
\hline I completely Agree & 5.00 & 4.20 \\
Agree & 4.19 & 3.40 \\
I Somewhat Agree & 3.39 & 2.60 \\
I Agree less & 2.59 & 1.80 \\
I Disagree & 1.79 & 1.00 \\
No Information & 0 & \\
\hline
\end{tabular}

\section{METHOD}

In this study, document analysis method was used to evaluate the 5th Grade Social Studies curriculum of secondary school in terms of its needs assessment, objectives, content and teaching-learning process and assessment process regarded to the compliance of curriculum development principles. Document analysis, used for collection of public or private records, studying and evaluating of them systematically, encompasses the analysis of written materials which involves information about targeted case or cases (Yıldırım \& Şimsek, 2005). In this context, it is aimed to evaluate the social studies curriculum in a systematic manner through the evaluation criteria based on conformity with the principles of curriculum development.

\section{Data Collection and Analysis}

At the stage of data collection, the literature related to basic elements of the curriculum was reviewed in order to determine needs and priorities of curriculum components (objectives, content, teachinglearning process and assessment process). As a result of literature review, a large number of criteria which demonstrate the features of the curriculum have been identified in order to create criteria pool. The necessary corrections on these defined numerous criteria were made and finalized by taking an expert's opinion*, who is working in Department of Education, in Curriculum and Instruction, in Faculty of Educational Sciences in Afyonkarahisar Kocatepe University, and three teachers ${ }^{* *}$ views who are making doctoral studies in the same field. The document analysis form which is developed to evaluate needs, objectives, content, teaching-learning process and assessment process of the curriculum is called as "Curriculum Evaluation Analysis Form $^{* * *}$ (AFCE). ${ }^{1}$

The analysis form is prepared in the form consists of five sections. The first part is "Needs Assessment"; the second part is "Objectives"; the third part is "Content"; the fourth part is "Teaching-Learning process" and the fifth part is "Assessment Process". These sections are developed by the teachers who are making doctoral studies in the field of of Curriculum and Instruction. The form was developed through examining the $5^{\text {th }}$ Grade of Curriculum Social Studies in Secondary School which was published by the Board of Education in 2013. However, the comment section of the 2005 curriculum which underlies this curriculum (does not exist in 2013 curriculum) and the publications of Board of Education's Curriculum Development Studies (Gömleksiz, 2005; MEB, 2005) have been used in the formation of Analysis Form.

used in the study is prepeared to use for other curriculums. This form was used also in the study entitled "The Evaluation of Elementary $4^{\text {th }}$ Grade Science Curriculum" which was presented in ICOINE2014 conference. 
Table 2. The evaluation table of the curriculum's need assessment component

\begin{tabular}{|c|c|c|c|c|}
\hline \multirow{2}{*}{ NEED ASSESSMENT } & \multicolumn{3}{|c|}{ OBSERVERS } & \multirow{2}{*}{ AVERAGE } \\
\hline & 1 & 2 & 3 & \\
\hline 1. When determining the needs, environmental and regional differences are taken into account. & 1.00 & 1.00 & 1.00 & 1.00 \\
\hline 2. Scientific developments are taken into account when determining the needs. & 5.00 & 5.00 & 5.00 & 5.00 \\
\hline \multicolumn{5}{|l|}{ 3. The overlap level of the needs with educational streams such as: } \\
\hline 3.a. Perennialism & 1.00 & 1.00 & 1.00 & 1.00 \\
\hline 3.b. Essentialism & 1.00 & 1.00 & 1.00 & 1.00 \\
\hline 3.c. Progressivism & 4.00 & 5.00 & 4.00 & 4.66 \\
\hline 3.d. Re-constructionism & 4.00 & 4.00 & 4.00 & 4.00 \\
\hline 4.a. Delphi technique is used. & 0 & 0 & 0 & 0 \\
\hline 4.b. Questionnaire development technique is used. & 0 & 0 & 0 & 0 \\
\hline 4.c. Dacum technique is used. & 0 & 0 & 0 & 0 \\
\hline 4.ç. Occupation analysis technique is used. & 0 & 0 & 0 & 0 \\
\hline 4.d. Measuring tools-testing technique is used. & 0 & 0 & 0 & 0 \\
\hline 4.e. Interview-group meetings technique is used. & 5.00 & 5.00 & 5.00 & 5.00 \\
\hline 4.f. Observation technique is used. & 0 & 0 & 0 & 0 \\
\hline 4.g. Literature review technique is used. & 5.00 & 5.00 & 5.00 & 5.00 \\
\hline 5.a. Experts Views & 5.00 & 5.00 & 5.00 & 5.00 \\
\hline 5.b. Students' Views & 5.00 & 5.00 & 5.00 & 5.00 \\
\hline 5.c. Teachers' Views & 5.00 & 5.00 & 5.00 & 5.00 \\
\hline 5.ç. Parents' Views & 5.00 & 5.00 & 5.00 & 5.00 \\
\hline 5.d. Managers' Views & 5.00 & 5.00 & 5.00 & 5.00 \\
\hline 5.e. Inspectors' Views & 5.00 & 5.00 & 5.00 & 5.00 \\
\hline 5.f. Non-governmental Organizations' Views & 5.00 & 5.00 & 5.00 & 5.00 \\
\hline \multicolumn{5}{|l|}{ 6. When determining the needs, the needs assessment approaches are used: } \\
\hline 6.a. Differences approach has been adopted. & 0 & 0 & 0 & 0 \\
\hline 6.b. Descriptive approach has been adopted. & 0 & 0 & 0 & 0 \\
\hline 6.c. Democratic approach has been adopted. & 4.00 & 4.00 & 4.00 & 4.00 \\
\hline 6.ç. Analytical approach has been adopted. & 4.00 & 4.00 & 4.00 & 4.00 \\
\hline \multicolumn{5}{|l|}{ 7. Determining the stage of the needs assessment: } \\
\hline 7.a. Preparatory work is carried out. & 5.00 & 5.00 & 5.00 & 5.00 \\
\hline 7.b. Data collection efforts are carried out. & 5.00 & 5.00 & 5.00 & 5.00 \\
\hline 7.c. Data analysis is carried out. & 5.00 & 5.00 & 5.00 & 5.00 \\
\hline 9. Needs assessment studies meet the needs of community & 4.00 & 4.00 & 4.00 & 4.00 \\
\hline
\end{tabular}

The percentage of agreement between the analysis executed by experts in order to ensure the reliability of the study was calculated (Miles \& Huberman, 1994). In this study, for this purpose, "Consensus/ (Consensus+Dissidence)*100” Miles \& Huberman's formula (1994) and the reliability coefficient was calculated as 0.8. According to Buyukozturk (2013), in order to accept the obtained value as reliable, percentage agreement must be above 0.7. Score range of items was calculated by the formula that Range Width $=($ String Width $) /($ Number of Groups). The score range was determined as $4.5=0.80$. (Tekin, 1996).

\section{FINDINGS}

In the study, the 5th Grade Social Studies Curriculum of secondary school in terms of its needs assessment, objectives, content and teaching-learning process and assessment process was evaluated throug the criteira in the analysis form which was developed by an expert of curriculum and instruction and three teachers who are making doctoral studies in the same field. Analysis form was filled individually by those three teachers and evaluated by calculating average scores.

Findings of the sub-problems:

1. What is the compliance level of the fifth grade social studies curriculum studies in terms of the needs assessment?

According to Table 2, it is seen that neither environmental nor regional differences has been considered while determining the needs.
The criterion of "when determining needs, the scientific progress are taken into account" was answered by the observers in "I Completely Agree" level. On the other hand, while the criterion of "the overlapping level of needs in terms of Progressivism and Re-constructionism" which were the educational streams of the curriculum's theoretical foundations was answered by the observers in "Agree" level, it is answered in "I Disagree" level in terms of Perennialism and Essentialism, while the criterion of "interview and literature techniques in the process of preparation of the curriculum" as needs assessment techniques was answered by observers in "I Completely Agree" degree. Therefore, it can be interpreted that the studies of need assessment of Social Studies Curriculum was carried out in accordance with the principles of curriculum development.

2. What is the compliance level of the fifth grade social studies curriculum studies in terms of the objectives component of the curriculum?

When the table of objectives (Table 3) is examined, the criterion of "the curriculum has overall and specific objectives" was answered by the observers in "I Completely Agree" level. It is seen that the criterion of "needs and specific objectives" was answered in "Agree" overlap level. When determining the objectives in Social Studies curriculum, it was found that neither the old nor the revised Bloom's taxonomy was taken into account. Additionally, it is observed tha the objectives are clear, understandable and clearly stated. It is seen that the objectives are listed from simple to complex, from easy to difficult. Generally, it can be interpreted through the findings of objectives component of the 
Table 3. The evaluation table of the curriculum's objectives component

\begin{tabular}{|c|c|c|c|c|}
\hline \multirow{2}{*}{ OBJECTIVES } & \multicolumn{3}{|c|}{ OBSERVERS } & \multirow{2}{*}{ AVERAGE } \\
\hline & 1 & 2 & 3 & \\
\hline 1. The overall objectives of the curriculum are stated. & 5.00 & 5.00 & 5.00 & 5.00 \\
\hline 2. The specific objectives of the curriculum are indicated. & 5.00 & 5.00 & 5.00 & 5.00 \\
\hline 3. Objectives overlap with the needs. & 4.00 & 4.00 & 3.00 & 3.66 \\
\hline 4. Objectives overlap with specific objectives. & 4.00 & 4.00 & 4.00 & 4.00 \\
\hline \multicolumn{5}{|l|}{ 5. The overlap of objectives with eduactional streams: } \\
\hline 5.a. Perennialism & 1.00 & 1.00 & 1.00 & 1.00 \\
\hline 5.b. Essentialism & 1.00 & 1.00 & 1.00 & 1.00 \\
\hline 5.ç. Progressivism & 4.00 & 5.00 & 5.00 & 4.66 \\
\hline 5.d. Re-constructionism & 4.00 & 4.00 & 4.00 & 4.00 \\
\hline 6. Bloom's Taxonomy is taken into consideration when determining objectives. & 1.00 & 1.00 & 1.00 & 1.00 \\
\hline 7. Bloom's Revised Taxonomy is taken into consideration when determining objectives. & 1.00 & 1.00 & 1.00 & 1.00 \\
\hline 8. Objectives express what students should do. & 5.00 & 5.00 & 5.00 & 5.00 \\
\hline 9. Objectives are based on learning products. & 4.00 & 4.00 & 4.00 & 4.00 \\
\hline 11. Objectives are feasible. & 4.00 & 4.00 & 4.00 & 4.00 \\
\hline 12. Objectives are achievable. & 4.00 & 4.00 & 4.00 & 4.00 \\
\hline 13. Objectives are achievable during an academic year. & 4.00 & 4.00 & 4.00 & 4.00 \\
\hline \multicolumn{5}{|l|}{ 14. Suitability of objectives with the readiness of students: } \\
\hline 14.a. Objectives are suitable for prior learning. & 4.00 & 4.00 & 4.00 & 4.00 \\
\hline 14.b. Objectives are suitable for students' developmental level. & 4.00 & 5.00 & 5.00 & 4.66 \\
\hline 14.c. Objectives are suitable for students' interest. & 4.00 & 3.00 & 2.00 & 3.00 \\
\hline 14.ç. Objectives are suitable for students' individual characteristics. & 4.00 & 3.00 & 22.00 & 3.00 \\
\hline 15. Objectives are clear, understandable and clearly stated. & 4.00 & 4.00 & 4.00 & 4.00 \\
\hline 16. Objectives are from easy to difficult and from simple to complex. & 4.00 & 4.00 & 4.00 & 4.00 \\
\hline
\end{tabular}

Table 4. The evaluation table of the curriculum's content component

\begin{tabular}{|c|c|c|c|c|}
\hline \multirow{2}{*}{ CONTENT } & \multicolumn{3}{|c|}{ OBSERVERS } & \multirow{2}{*}{ AVERAGE } \\
\hline & 1 & 2 & 3 & \\
\hline 1. Content overlaps with objectives & 4.00 & 4.00 & 4.00 & 4.00 \\
\hline 2. Curriculum answers the question "What will we teach?" & 4.00 & 4.00 & 4.00 & 4.00 \\
\hline 3. Objectives of units are suitably shared in time of units. & 4.00 & 3.00 & 4.00 & 3.66 \\
\hline 4. Topics of units consist of extensive information. & 5.00 & 4.00 & 4.00 & 4.33 \\
\hline 5. Content is feasible. & 4.00 & 4.00 & 4.00 & 4.00 \\
\hline 6. There is a relation between topics and activities & 4.00 & 4.00 & 4.00 & 4.00 \\
\hline 7. Topics are suitable for students' readiness. & 3.00 & 3.00 & 3.00 & 3.00 \\
\hline 8. Content is organized from simple to difficult. & 4.00 & 4.00 & 4.00 & 4.00 \\
\hline 9. Topics and concepts are repeated at regular intervals. & 4.00 & 4.00 & 4.00 & 4.00 \\
\hline 10. Topics are prerequisite of each other. & 3.00 & 4.00 & 4.00 & 3.66 \\
\hline 11. Content is organized into modules. & 1.00 & 1.00 & 1.00 & 1.00 \\
\hline 12. There is a relation between interdisciplinary objevtives and the objectives of units. & 2.00 & 2.00 & 2.00 & 2.00 \\
\hline \multicolumn{5}{|l|}{ 13. There is a relation between objectives of units and basic skills: } \\
\hline 13.b. There is a relation between objevtives and creative thinking. & 4.00 & 4.00 & 4.00 & 4.00 \\
\hline 13.c. There is a relation between objectives and communication skills & 4.00 & 4.00 & 4.00 & 4.00 \\
\hline 13.d. There is a relation between objectives and questions ability. & 4.00 & 4.00 & 4.00 & 4.00 \\
\hline 13.e. There is a relation between objectives and problem solving skills. & 4.00 & 4.00 & 4.00 & 4.00 \\
\hline 13.f. There is a relation between objectives and information technology. & 4.00 & 4.00 & 4.00 & 4.00 \\
\hline 13.g. There is a realtion between objecitves and enterpreneurial skills. & 4.00 & 4.00 & 4.00 & 4.00 \\
\hline 13.h. There is a relation between objectves and using Turkish right, effective and well. & 4.00 & 4.00 & 4.00 & 4.00 \\
\hline 14- There is a relation between content and real life. & 4.00 & 4.00 & 3.00 & 3.66 \\
\hline
\end{tabular}

curriculum that the objectives studies of the Fifth Grade Social Studies Curriculum are carried out in accordance with the principles of curriculum development.

3. What is the compliance level of the fifth grade social studies curriculum studies in terms of the content component of the curriculum?

According to Table 4, it is observed that the content is compatible with the objectives and it is seen that curriculum answers the question "What will we teach?". While the criterion of "Objectives of units are suitably shared in time of units" is answered by the observers in "I Agree" level, they express their opinion for the criterion "Topics of units consist of extensive information" in "I Completely Agree" level. On the other hand, while the content is found to be applicable, it is seen that curriculum activities have been correlated with the subject. However, observers' opinions subject to the student's level of readiness is "I Somewhat Agree". In addition, according to the observers, it is observed that the content is arranged from simple to difficult; subjects and concepts are repeated at regular intervals and subjects are 
Table 5. The evaluation of the curriculum's learning and teaching process

\begin{tabular}{|c|c|c|c|c|}
\hline \multirow{2}{*}{ TEACHING-LEARNING PROCESS } & \multicolumn{3}{|c|}{ OBSERVERS } & \multirow{2}{*}{ AVERAGE } \\
\hline & 1 & 2 & 3 & \\
\hline 1. Teaching strategies and methods / techniques have been associated with objectives. & 4.00 & 4.00 & 4.00 & 4.00 \\
\hline 2. The practices in teaching-learning process is consistent with the curriculum's objectives. & 4.00 & 4.00 & 4.00 & 4.00 \\
\hline \multicolumn{5}{|l|}{ 3. The defined learning experiences' overlapping level in terms of: } \\
\hline 3. a.Student's interest & 4.00 & 4.00 & 4.00 & 4.00 \\
\hline 3. b. Students' prior learning & 4.00 & 3.00 & 3.00 & 3.33 \\
\hline 3. c. Students' developmental level & 4.00 & 4.00 & 3.00 & 3.66 \\
\hline 4. The defined learning experiences of the curriculum is accordance with the affordability principle of the curriculum. & 4.00 & 4.00 & 4.00 & 4.00 \\
\hline 6. The defined learning experiences in itself is associated with other learning experiences. & 4.00 & 4.00 & 4.00 & 4.00 \\
\hline \multicolumn{5}{|l|}{ 7. The defined learning experiences of upper-lower class relations: } \\
\hline 7. a. Supports the upper class. & 4.00 & 4.00 & 4.00 & 4.00 \\
\hline 7. b. Reinforces lower class. & 4.00 & 4.00 & 4.00 & 4.00 \\
\hline 8. The defined learning experiences in the curriculum are selected in accordance with the principle of progressivity. & 4.00 & 4.00 & 4.00 & 4.00 \\
\hline 9. Learning experiences are listed in accordance with the principles and the policy of teaching-learning process. & 4.00 & 4.00 & 4.00 & 4.00 \\
\hline 10. The proposed teaching-learning approaches in the curriculum are selected according to subject area. & 4.00 & 4.00 & 4.00 & 4.00 \\
\hline \multicolumn{5}{|l|}{ 11. The defined teaching-learning process improves the quality of basic life skills such as: } \\
\hline 11. b. Creative thinking & 4.00 & 4.00 & 4.00 & 4.00 \\
\hline 11. c. Research, inquiry and decision making skills & 4.00 & 4.00 & 4.00 & 4.00 \\
\hline 11. d. Problem solving skills & 4.00 & 4.00 & 4.00 & 4.00 \\
\hline 11. e. Communication skills & 4.00 & 4.00 & 4.00 & 4.00 \\
\hline 11. f. UsingTurkish right, good and effectively way & 4.00 & 4.00 & 4.00 & 4.00 \\
\hline 11. g. Entrepreneurial skills & 4.00 & 4.00 & 4.00 & 4.00 \\
\hline 11. h. Ability to use information technology & 4.00 & 4.00 & 4.00 & 4.00 \\
\hline \multicolumn{5}{|l|}{ 12. Teaching-learning process: } \\
\hline 12. a. Supports 5E model. & 4.00 & 4.00 & 4.00 & 4.00 \\
\hline 12. b. Seems to support discussion methods (debates, panel discussions, open forums etc.). & 4.00 & 4.00 & 4.00 & 4.00 \\
\hline 12. c. Supports teacher-centered methods (lectures, question-answer etc.). & 1.00 & 1.00 & 1.00 & 1.00 \\
\hline 12. d. Supports group teaching methods. & 4.00 & 4.00 & 4.00 & 4.00 \\
\hline 13. Teachers are directed to be granted special teaching methods of the course in the curriculum. & 4.00 & 4.00 & 4.00 & 4.00 \\
\hline 14. The teaching-learning process directs teachers are to make preparations before the course. & 4.00 & 4.00 & 4.00 & 4.00 \\
\hline 15- Learning experiences direct teacher to make assessment. & 4.00 & 4.00 & 4.00 & 4.00 \\
\hline \multicolumn{5}{|l|}{ 16- Curriculum's level in terms of directing teachers to use teaching-learning process variables such as: } \\
\hline 16. c. Feedback. & 2.00 & 2.00 & 2.00 & 2.00 \\
\hline 17. Teaching-Learning process encourages student participation. & 4.00 & 4.00 & 3.00 & 3.66 \\
\hline 18.Teaching-Learning process is associated with learning areas. & 4.00 & 4.00 & 4.00 & 4.00 \\
\hline \multicolumn{5}{|l|}{ 19. The flexibility level of the activities in the teaching-learning process in terms of: } \\
\hline 19. a. Time & 1.00 & 1.00 & 1.00 & 1.00 \\
\hline 19. b. Region & 1.00 & 1.00 & 1.00 & 1.00 \\
\hline 19. c. Developmental characteristics & 4.00 & 3.00 & 4.00 & 3.66 \\
\hline 19. d. taking account of prior learning. & 4.00 & 3.00 & 4.00 & 3.66 \\
\hline \multicolumn{5}{|l|}{ 20- The examples related to the courses are: } \\
\hline 20. a. Student-centered & 4.00 & 4.00 & 4.00 & 4.00 \\
\hline 20. b. Teacher-centered & 1.00 & 1.00 & 1.00 & 1.00 \\
\hline 21. The teaching-learning process makes the choice of material easy for teacher. & 2.00 & 2.00 & 2.00 & 2.00 \\
\hline 22. The relationship between the suggested methods and techniques of the curriculum and learning styles has been established. & 3.00 & 2.00 & 3.00 & 2.66 \\
\hline $\begin{array}{l}\text { 23. The final activities such as discussion questions, trip, observation, experiment, summarizing, producing guide teachers } \\
\text { effectiveness is a guiding nature. }\end{array}$ & 3.00 & 3.00 & 3.00 & 2.66 \\
\hline 24. The classroom layout is stated in the curriculum. & 1.00 & 1.00 & 1.00 & 1.00 \\
\hline 25- The curriculum leads teachers to effective classroom management. & 1.00 & 1.00 & 1.00 & 1.00 \\
\hline 26- The time allocated for the teaching-learning activities is sufficient. & 1.00 & 1.00 & 1.00 & 1.00 \\
\hline 27- The activities seem to guide students. & 4.00 & 4.00 & 4.00 & 4.00 \\
\hline 28- The activities seem to guide teachers. & 4.00 & 4.00 & 4.00 & 4.00 \\
\hline 29- Teaching-learning activities can be performed. & 4.00 & 4.00 & 4.00 & 4.00 \\
\hline
\end{tabular}

prerequisite for each other. According to the findings, the content component of the Fifth Grade Social Studies Curriculum are carried out in accordance with the principles of curriculum development, except for the criterion of "Topics are suitable for students' readiness" and "There is a relation between interdisciplinary objevtives and the objectives of units".

4. What is the compliance level of the fifth grade social studies curriculum studies in terms of the teaching-learning process of the curriculum?
When Table 5 is examined, the findings show that teaching strategies and methods / techniques have been associated with objectives and the practices in teaching-learning process is consistent with the curriculum's objectives. While the observers express their opinion for the criterion of "The defined learning experiences' overlapping level in terms of student's interest and developmental level" in "I Agree" level, they indicate their opinion in "I Somewhat Agree" level in terms of students' prior learning. It is observed that the curriculum directs theachers to use special instruction methods, to make assessment activities. However, it is found that new curriculum seems insufficient to use learning process variables (reinforcement, tips 
Table 6. The evaluation table of the curriculum's assessment process component

\begin{tabular}{|c|c|c|c|c|}
\hline \multirow{2}{*}{ ASSESSMENT PROCESS } & \multicolumn{3}{|c|}{ OBSERVERS } & \multirow{2}{*}{ AVERAGE } \\
\hline & 1 & 2 & 3 & \\
\hline 1. The curriculum has a part of the assessment. & 5.00 & 5.00 & 5.00 & 5.00 \\
\hline 2- The assessment part of the curriculum shows how to test samples of the objectives. & 4.00 & 4.00 & 4.00 & 4.00 \\
\hline 3- The examples given for assessment process measure the level of learning of related subjects. & 4.00 & 4.00 & 4.00 & 4.00 \\
\hline 4-The examples given for assessment process are associated with the taxonomy of the objecitves. & 1.00 & 1.00 & 1.00 & 1.00 \\
\hline $\begin{array}{l}\text { 5- The curriculum directs teachers to use alternative assessment and evaluation tools in the process of evaluation } \\
\text { of objectives. }\end{array}$ & 5.00 & 5.00 & 5.00 & 5.00 \\
\hline 6- The curriculum gives information how to use assessment and evaluation tools. & 4.00 & 4.00 & 4.00 & 4.00 \\
\hline \multicolumn{5}{|l|}{ 7- The usage level of examples for assessment and evaluation tools: } \\
\hline 7.a. It is directed to product. & 4.00 & 4.00 & 4.00 & 4.00 \\
\hline 7.b. It is directed to process. & 4.00 & 4.00 & 4.00 & 4.00 \\
\hline 8 - At the end of each unit there are measurement tools to determine the level of students. & 4.00 & 4.00 & 4.00 & 4.00 \\
\hline \multicolumn{5}{|l|}{ 9- Student's level of participation in the assessment process: } \\
\hline 9.a. There are measurement tools for self-assessment. & 5.00 & 5.00 & 5.00 & 5.00 \\
\hline 9.c. There are measurement tools for group assessment. & 5.00 & 5.00 & 5.00 & 5.00 \\
\hline 10- There is table of indicators. & 1.00 & 1.00 & 1.00 & 1.00 \\
\hline 11- Explanations for the assessment of the measurement results are included. & 4.00 & 4.00 & 4.00 & 4.00 \\
\hline
\end{tabular}

and feedback). In addition to this, it is determined that the new curriculum has no information about the layout of class. While the new curriculum does not lead teachers on effective classroom management, it is observed that the time allocated for the teaching-learning activities are not enough. Activities for both students and teachers are guiding and activities are achievable. In summary, according to the findings, it can be said that the teaching-learning process of the Fifth Grade Social Studies Curriculum is carried out in accordance with the principles of curriculum development in terms of some criteria. On the other hand, it is found insufficient in terms of some criteria such as using learning process variables (reinforcement, tips and feedback) and establishing relationship between methods/techniques and learning styles.

5. What is the compliance level of the fifth grade social studies curriculum studies in terms of the assessment process component of the curriculum?

According to Table 6, when the the assessment process of the curriculum is examined, the criterion of "The curriculum has a part of the assessment" and "the assessment part of the curriculum shows how to test samples of the objectives" and "the examples given for assessment process measure the level of learning of related subjects" are answered in "I Very Agree" level. On the other hand, it is identified that the examples given for assessment process are not associated with the taxonomy of the objectives. According to the findings, it can be generally concluded that the assessment component of the Fifth Grade Social Studies Curriculum are carried out in accordance with the principles of curriculum development.

\section{CONCLUSION AND DISCUSSION}

According to the findings obtained about need assessment component of the curriculum, it can be concluded that neither environmental nor regional differences has been considered while determining the needs. Except for his criterion, it can be said that the studies of need assessment of the Fifth Social Studies Curriculum was carried out in accordance with the principles of curriculum development. It would be useful to take steps to improve the effectiveness and functionality of The Educational Regions and Board of Education in provincial and district centers for the neglected "locality" part of the curriculum through empowerment in order to solve this neglected part of the curriculum (Turan, Dönmez ve Çakmak, 2009). And also it can be generally said that the objectives component of the Fifth Social Studies Curriculum is carried out in accordance with the principles of curriculum development. It it was found that neither the old nor the revised Bloom's taxonomy are taken into account and there is no explanation about the taxonomy of the objectives as well. Furthermore the objectives are not found suitable in terms of students' individual characteristics and interests. It is observed that these results are consistent with Doğanay (2008) and Kayhan \& Tokcan's (2013) findings. Although the curriculum's content component is found in accordance with the principles of curriculum development, it is criticized becuase of not taking account of students' readiness and insufficient relationship between interdiciplinary objectives and unit objecitves. Yaşar (2005) ve Keçe and Meyer's (2011) studies support these results.

The assessment processs of the curriculum are criticized for the cases such as being inadequate to use teaching-learning process variables such as (reinforcement, clue and feedback) and establishing insufficient relationship between the methods proposed by the curriculum and learning styles. Additionally, neither time nor region is flexible in teaching-learning processs and the process does not make the choice of material easy for teacher. Moreover, the curriculum is severely criticized for stating no classroom layout and effective clasroom management and insufficient time for teaching-learning activities. It is observed that these results are consistent with Karacaoğlu's (2010) findings. It can be generally said that the teachinglearning process component of the Fifth Social Studies Curriculum is partially carried out in accordance with the principles of curriculum development because of these criticized aspects. On the other hand, the assessment process of the curriculum is generally found in accordance with the principles of curriculum development, except for the cases that not being associated with the taxonomy of the objectives and not having table of indicators. These results are consistience with Tarman, Ergür and Eryıldız's (2012) findings. 


\section{REFERENCES}

Adanalı, K. (2008). Sosyal bilgiler eğitiminde alternatif değerlendirme: 5 . simf sosyal bilgiler eğitiminin alternatif değerlendirme etkinlikleri açısıdan değerlendirilmesi. Unpublished Master Thesis, Çukurova Üniversitesi, Adana.

Akengin, A., \& Demirsoy, M. (2011). Dördüncü ve Beşinci Sınıf Öğrencilerinin Sosyal Bilgiler Dersine İlişkin Görüşleri. M.Ü. Atatürk Eğitim Fakültesi Eğitim Bilimleri Dergisi, (33), 5-23.

Arslan, A., \& Şahiner, S. (2010). Sosyal Bilgiler Öğretim Programında (4. - 5. Sinıflar) Önerilen Tutum ve Öz Değerlendirme Ölçme Araçlarının Geçerliliği ve GüvenirliğiÜzerine Bir Çalışma. Mustafa Kemal UniversityJournal of Social Sciences Institute, 7(14), 195-208.

Aslan, A., \& Tetik, A. (2013). İlköğretim 5. Sınıf Sosyal Bilgiler Programı Kazanımlarının Ulaşılma Düzeyinin Belirlenmesi. Bartın Üniversitesi Eğitim Fakültesi Dergisi, 2(2), 280-294. https://doi.org/10.14686/201321990

Ataman, M., \& Kabapınar, Y. (2012). Sosyal Bilgiler (4-5. Sinif) Programlarındaki Ölçme Değerlendirme Yöntemlerinin Kullanılma Nedenleri ve Uygulamaların Yeterliliği. Amasya Üniversitesi Eğitim Fakültesi Dergisi, 1(1), 94-114.

Aykaç, N. (2007). İlköğretim Sosyal Bilgiler Dersi Eğitim-Öğretim Programına Yönelik Öğretmen Görüşleri. Elektronik Sosyal Bilimler Dergisi, 6(22), 46-73.

Büyüköztürk, Ş., Kılıç Çakmak, E., Akgün, Ö. E., Karadeniz, Ş., \& Demirel, F. (2013). Bilimsel Araștırma Yöntemleri. Ankara: Pegem Yayınevi.

Doğanay, A. (2008). Çağdaş Sosyal Bilgiler Anlayışı Işs̆ğında Yeni Sosyal Bilgiler Curriculumının Değerlendirilmesi. Ç. Ü. Sosyal Bilimler Enstitüsü Dergisi, 17(2), 77-96.

ERG Report (2005). Yeni öğretim programlanm inceleme ve değerlendirme raporu. http://www.erg.sabanciuniv.edu/docs/mufredat_raporu doc

Ersoy, A. F., \& Kaya, E. (2009). Sosyal Bilgiler Dersi Öğretim Programının (2004) Uygulama Süresine İlişkin Öğrenci Görüşleri. Kastamonu Eğitim Dergisi, 17(1), 71-86.

Gelbal, S., \& Kelecioglu, H. (2007). Öğretmenlerin Ölçme ve Değerlendirme Yöntemleri Hakkındaki Yeterlik Algıları ve Karşılaştıkları Sorunlar. Hacettepe Üniversitesi Eğitim Fakültesi Dergisi (H. U. Journal of Education), 33, 135-145.

Gömleksiz, M. N., \& Öner, Ü. (2013). Sosyal Bilgiler Dersinde Yapılandırmacı Öğrenme-Öğretme Sürecine İlişkin Öğrenci Görüşlerinin Çeçitli Değişkenler Açısından Değerlendirmesi. Adryaman Üniversitesi Sosyal Bilimler Enstitüsü Dergisi, 14, 282-308.

Gömleksiz, M., Yaşar, Ş., Sağlam, M., Hakan, A., Sözer, E., Gözütok, D., Saylan, N., Battal, N., Yildiran, G., Kaya, Z., Ulusoy, A., Aksu, M., \& Yildirim, A. (2005). Yeni Öğretim Programlarını İnceleme ve Değerlendirme Raporu. Elementary Education Online, 5(1).
İnce, M. (2005). İlköğretim Ders Müfredatlarının Değiştirilme Süreci Üzerine Bir Değerlendirme. Eğitim Politikalan-Online Eğitim Dergisi, 1, 1. http://www.egitimpolitikalari.com/sayı1/ince.doc

Kalaycığlu, E. (2007). İlköğretim 4. ve 5. Sınıf Sosyal Bilgiler Programının Öğretmen Görüşlerine Göre Değerlendirilmesi. Master Thesis. Atatürk Üniversitesi, Erzurum.

Karacaoğlu, Ö. C. (2010). Yenilenen Programların Uygulamasında Öğretmenlerin Karşılaştığı Sorunlar. Yüzüncü Yıl Üniversitesi, Eğitim Fakültesi Dergisi, 7(1), 45-58.

Kayhan, C., \& Tokcan, H. (2013). İlköğretim Sosyal Bilgiler 4. ve 5. Sınıf Ünite Kazanımları ile Ders Kitapları Hazırlık ve Değerlendirme Sorularının Bilişsel, Duyuşsal ve Psikomotor Hedefler Açısından Karșılaștırılması. The Journal of Academic Social Science Studies, 6(3), 685-700.

Keçe, M., \& Merey, Z. (2011). İlköğretim Sosyal Bilgiler Kazanımlarının Sosyal Bilimler Disiplinlerine ve Disiplinler arası Anlayışa Uygunluğunun Belirlenmesi. Yüzüncü Yll Üniversitesi, Eğitim Fakültesi Dergisi, 8(1), 110-139.

Kesten, A., \& Özdemir, N. (2010). Sosyal Bilgiler Öğretim Curriculumının Ölçme Değerlendirme Boyutunun Öğretmen Görüşlerine Göre Değerlendirilmesi: Samsun İli Örneği. Firat Üniversitesi Sosyal Bilimler Dergisi (Firat University Journal of Social Science), 20(2), 223-236.

MEB (2005). Sosyal Bilgiler Öğretim Programı. ttkb.meb.gov.tr/program2.aspx

National Council for the Social Studies (NCSS) (1994). Expectations of Excellence: Curriculum Standards for Social Studies.

Semenderoğlu, A., \& Gülersoy, A. E. (2005). Eski ve Yeni 4. ve Sosyal Bilgiler Öğretim Curriculumlarının Değerlendirmesi. Dokuz Eylül Üniversitesi, Buca Eğitim Fakültesi Dergisi, 18, 141-152.

Tarman, B., Ergür, Ş., \& Eryıldız, F. (2012). Yenilenen Sosyal Bilgiler Curriculumına Dair Bir Değerlendirme. Gaziantep Üniversitesi Sosyal Bilimler Dergisi, 11(1), 103-135.

Tekin, H. (1996). Eğitimde Ölçme ve Değerlendirme. 9. Baskı. Ankara: Yarg1 Yayınları.

Turan, S., Dönmez, A., \& Çakmak, G. (2009). İlköğretim Okullarındaki Bazı Kurulların Etkililiği Üzerine Bir İnceleme. Uşak Üniversitesi Sosyal Bilimler Dergisi, 2(2), 44-45. https://doi.org/10.12780/ UUSBD56

Yaşar, Ş. (2005). Sosyal Bilgiler Programı ve Öğretimi. Yeni İlköğretim Programlann Değerlendirme Sempozyumu, Erciyes Üniversitesi, Kayseri, 329-342.

Yıldırım, A., \& Şimşek, H. (2005). Sosyal Bilimlerde Nitel Araştırma Yöntemleri. Ankara: Seçkin Yayıncıllk. 